\title{
Comparison of potassium-functionalized Cu2ZnSnS4 nanoparticles annealed in different reactive sulfide atmospheres
}

\author{
Engberg, Sara Lena Josefin; Canulescu, Stela; Schjodt, Niels Christian; Schou, Jørgen
}

Published in:

Proceedings of the 7th World Conference on Photovoltaic Energy Conversion

Link to article, DOI:

10.1109/PVSC.2018.8547332

Publication date:

2018

Document Version

Peer reviewed version

Link back to DTU Orbit

Citation (APA):

Engberg, S. L. J., Canulescu, S., Schjodt, N. C., \& Schou, J. (2018). Comparison of potassium-functionalized Cu2ZnSnS4 nanoparticles annealed in different reactive sulfide atmospheres. In Proceedings of the 7th World Conference on Photovoltaic Energy Conversion (pp. 0124-0126). IEEE. https://doi.org/10.1109/PVSC.2018.8547332

\section{General rights}

Copyright and moral rights for the publications made accessible in the public portal are retained by the authors and/or other copyright owners and it is a condition of accessing publications that users recognise and abide by the legal requirements associated with these rights.

- Users may download and print one copy of any publication from the public portal for the purpose of private study or research.

- You may not further distribute the material or use it for any profit-making activity or commercial gain

- You may freely distribute the URL identifying the publication in the public portal 


\title{
Comparison of potassium-functionalized $\mathrm{Cu}_{2} \mathrm{ZnSnS}_{4}$ nanoparticles annealed in different reactive sulfide atmospheres
}

\author{
Sara Engberg ${ }^{1}$, Stela Canulescu ${ }^{1}$, Niels Christian Schjødt ${ }^{2}$, and Jørgen Schou ${ }^{1}$ \\ ${ }^{1}$ DTU Fotonik, Technical Univeristy of Denmark, DK-4000 Roskilde, Denmark \\ ${ }^{1}$ Haldor Topsøe A/S, Haldor Topsøes Allé 1, DK-2800 Kgs. Lyngby, Denmark
}

\begin{abstract}
Kesterite $\mathrm{Cu}_{2} \mathrm{ZnSnS}_{4}$ (CZTS) can be a promising, alternative material for thin-film solar cells, because it is earthabundant, non-toxic and displays relevant physical properties. For future up-scaling possibilities and to decrease the environmental impact of the photovoltaic technology, solutionprocessing deposition methods are desired. This paper deals with CZTS absorber layers fabricated from CZTS nanoparticles that are functionalized with $\mathrm{KCl}$, and investigates two different types of furnaces for the annealing process; a hydrogen sulfide $\left(\mathrm{H}_{2} \mathrm{~S}\right)$ flow furnace and a nitrogen atmosphere closed furnace. We find that more uniform grain growth is achieved when annealing in a closed furnace, while very large grains on the surface of the film are obtained when annealing in $\mathrm{H}_{2} \mathrm{~S}$.
\end{abstract}

Index Terms - $\mathrm{Cu}_{2} \mathrm{ZnSnS}_{4}$, nanoparticles, annealing, grain growth.

\section{INTRODUCTION}

Thin-film photovoltaics consisting of $\mathrm{CuInGaSe}_{2}$ and CdTe as the absorber layer exhibits high power conversion efficiencies of $22.6 \%$ and $22.1 \%$, respectively, and composes a share of around $10 \%$ of the world solar panel market [1]. However, due to the relatively poor material abundance of In, $\mathrm{Ga}$, and to some extent Te, and the eco-toxicity of Ga and Cd, it is crucial to look for substituting compounds. Here, $\mathrm{Cu}_{2} \mathrm{ZnSnS}_{4}$ (CZTS) is one promising alternative. CZTS has reached a record efficiency of $11.0 \%$, it has a high absorption coefficient of $>10^{4} \mathrm{~cm}^{-1}$, and a direct energy band gap of 1.45 $\mathrm{eV}$, which additionally makes it an interesting material for a tandem solar cell with silicon [2].

The work presented in this paper concerns CZTS thin films fabricated from nanoparticle inks, which should offer largearea deposition through inexpensive means. One challenge faced in this field of solution-processing is to achieve a film morphology that is similar to that of vacuum deposited films; annealed nanoparticle thin films are commonly small-grained and porous [3], or contain the so-called fine-grain layer [4]. This fine-grain layer mostly comprises of nanoparticles in an organic material matrix - a result of the long and bulky organic molecules necessary to stabilize the particles in a solution. As grain boundaries are believed to be a site for recombination for the charge carriers, large grains are desired. Additionally, to enhance carrier transport, the porosity of the material should be minimized. The effect of the fine-grain layer is unknown, however as it contains very small grains and organic material, it should preferably be avoided.

\section{EXPERIMENTAL PROCEDURE}

Thin-film fabrication was carried out in the following steps: nanoparticle synthesis, ink formulation, thin-film deposition, and annealing.

The nanoparticles were synthesized using a one-step, hotinjection method, as described in our previous work [5]. Following the cleaning and collection of the particles, they were functionalized with $\mathrm{K}$ on the surface via a simple ligandexchange step [6]. $\mathrm{KCl}$ was dissolved in DI water and mixed with the nanoparticles dispersed in ethanol.

Films were deposited via a drop-casting method onto Mocoated soda lime glass (SLG) substrates, and blow-dried under a flow of nitrogen. This did not result in uniform films; however, it was sufficient to study the material properties relevant for this investigation.

Annealing was carried out in two different atmospheres, $\mathrm{H}_{2} \mathrm{~S}$ and $\mathrm{N}_{2}$. The $\mathrm{H}_{2} \mathrm{~S}$ annealing took place in a tube furnace, under a constant flow of a $\mathrm{H}_{2} \mathrm{~S}$ and $\mathrm{N}_{2}$ mixture. On the other hand, for the $\mathrm{N}_{2}$ annealing, the samples were placed in a graphite box with additional $100 \mathrm{mg}$ of $\mathrm{S}$ powder, and the chamber was pumped down and filled with 100 mbar nitrogen. For both processes, a ramp rate of $12 \mathrm{~K} / \mathrm{min}$ were used, and annealing temperature of $600^{\circ} \mathrm{C}$ for $30 \mathrm{~min}$, and the cooling occurred naturally (approx. $6 \mathrm{~h}$ to reach a $100^{\circ} \mathrm{C}$ ).

Characterization of the morphology was done with a scanning electron microscope (SEM) on a Quanta FEG. The composition was determined by energy dispersive X-ray spectroscopy (EDX) with a Bruker Quantax 70 system on a TM3000 tabletop microscope from Hitachi with an accelerating voltage of $15 \mathrm{kV}$. X-ray diffraction (XRD) was carried out with a Bruker D8 Advance system at $40 \mathrm{kV}$ and 40 $\mathrm{mA}$ using $\mathrm{Cu} \mathrm{K}_{\alpha}$-radiation. The $\mathrm{K}_{\alpha 2}$-signal and background were subtracted from the patterns using the program EVA. A photoluminescence mapper from Accent RPM2000 was used to measure the photoluminescence intensity of the samples with an excitation wavelength of $532 \mathrm{~nm}$ and power density of $100 \mathrm{~mW} / \mathrm{cm}^{2}$. 


\section{RESULTS AND DISCUSSION}

In the following sections, a presentation of the morphological and phase evolution, as well as relevant optoelectronic properties are presented for K-functionalized nanoparticles annealed under different annealing conditions. The composition of the as-synthesized nanoparticles was $\mathrm{Cu}_{1.9} \mathrm{Zn}_{1.6} \mathrm{SnS}_{4}$, which corresponds to the desired $\mathrm{Cu}$-poor and Zn-rich composition that is important for the achievement of high power conversion efficiency in these thin-film devices.

\section{A. Morphology}

The thermal treatment clearly has an effect on the morphology (Fig. 1). The SEM images show that the asdeposited sample is small-grained and porous of texture, while the S-sample is dense with large grains, and the $\mathrm{H}_{2} \mathrm{~S}$ sample displays some very large inhomogeneous grains on the surface. The sulfur sample furthermore contains some smaller brighterlooking grains, which earlier have been discovered to be a Sn-S phase. We suggest that the difference in structural evolution between the two annealed samples relates to the environment of the reactive sulfur during the annealing. To explain, during the S-annealing, $\mathrm{S}_{8}$-rings crack at a higher temperature, and since their sticking coefficient is higher on alkali elements than on the kesterite, they will deposit on the potassium to form a liquid K-S-phase - similar to what was discovered in [7]. This liquid phase, the reactive sulfur, can aid the merging of the nanoparticles, as a kind of fluxing agent. Therefore, the particles can sinter and coarsen, and the resulting film has a dense texture. On the contrary, for the $\mathrm{H}_{2} \mathrm{~S}$-annealing, the reactive sulfur is in the form of the $\mathrm{H}_{2} \mathrm{~S}$-molecules. Cation from the bulk of the film can diffuse to the surface where they crystallize with the sulfur from the $\mathrm{H}_{2} \mathrm{~S}$ to create new CZTS grains. This results in grains growing on the surface of the films. Further investigations into the matter could reveal whether the combined effect of the two types of thermal treatments could improve the morphology of the films further.
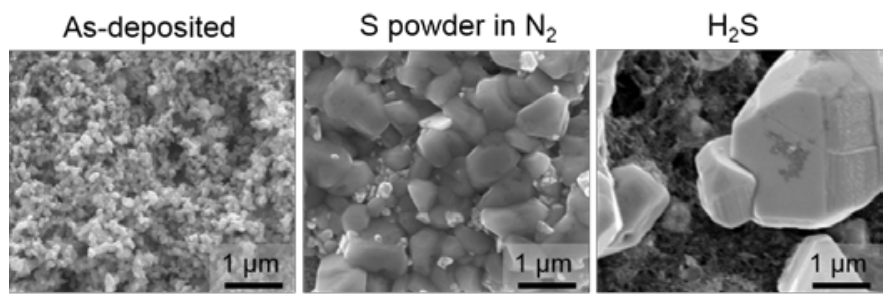

Fig. 1. Top-view SEM images of as-deposited CZTS nanoparticle thin-films and annealed in two different furnaces. A dense film with micron-sized grains is achieved for the film annealed under nitrogen atmosphere, while very large grains on the surface of the film are formed when annealing under a $\mathrm{H}_{2} \mathrm{~S}$ flow.

\section{B. Phase characterization}

The XRD patterns in Fig. 2 show the reflections of the films before and after annealing, as well as the CZTS reference spectrum (ICSD collection code 171983). The as-synthesized nanoparticles display the three main kesterite Bragg reflections, and a full width half maximum (FWHM) of 0.66 degrees. This corresponds to a grain size of $12 \mathrm{~nm}$ according to the Scherrer equation, when assuming spherical particles and no effect from strain broadening. The film annealed in $\mathrm{H}_{2} \mathrm{~S}$ displays only the relevant CZTS peaks (in addition to the Mo-substrate peak, as marked on the graph). In addition to the kesterite reflections, the film annealed in a closed nitrogen furnace also reveals an additional peak at 31.8 degrees, indicative of a $\mathrm{SnS}_{2}$ secondary phase (ICSD collection code 24376). FWHM of 0.10 degrees and 0.08 degrees, respectively, suggests that the grains have grown to $80 \mathrm{~nm}$ and $110 \mathrm{~nm}$ after the thermal treatments in $\mathrm{H}_{2} \mathrm{~S}$ and $\mathrm{N}_{2}$.

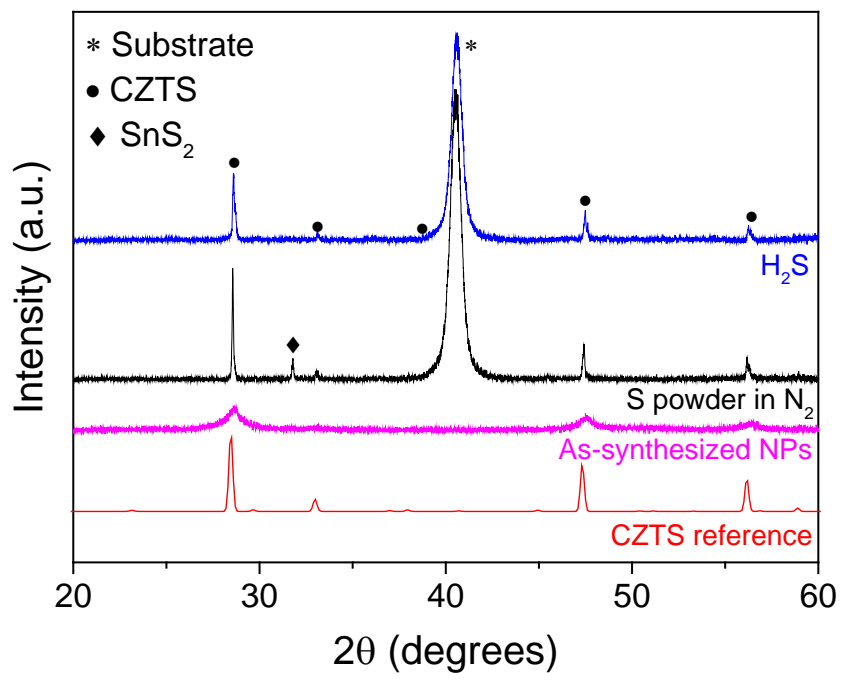

Fig. 2. XRD patterns of as-synthesized nanoparticles and thin-films annealed in the two different furnaces. The data display several kesterite CZTS reflections, however the film annealed in the closed nitrogen furnace also reveals what could be a $\mathrm{SnS}_{2}$ secondary phase.

\section{Opto-electronic properties}

The room-temperature photoluminescence spectra show a significant increase in radiative recombination rate for both types of heat treatment when compared to the as-deposited sample (Fig. 3). Furthermore, the closed nitrogen furnace produces films with higher photoluminescence intensity, suggesting the presence of fewer traps in this material. The peak is located at $1.33 \mathrm{eV}$ and $1.40 \mathrm{eV}$ for the S-sample and the $\mathrm{H}_{2} \mathrm{~S}$-sample, respectively. 


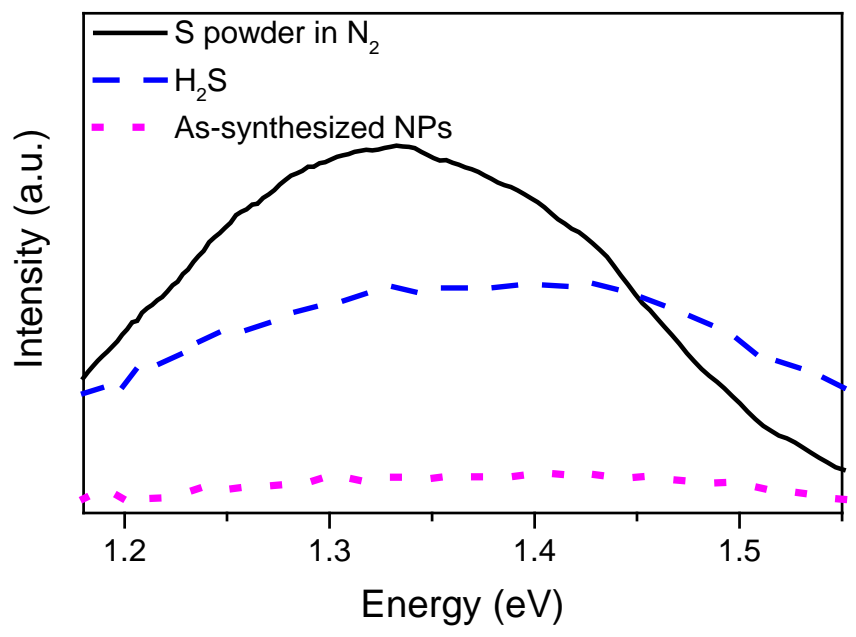

Fig. 3. Room-temperature photoluminescence spectra of assynthesized nanoparticles and thin-films annealed in the two different furnaces. The films annealed in nitrogen atmosphere display a higher intensity, indicating fewer defects in the material, and a peak-shift to lower energies.

\section{CONCLUSION}

When functionalizing CZTS nanoparticles with $\mathrm{KCl}$, more grain growth can be obtain within the film when annealing in a $\mathrm{S}$-atmosphere, while large grains appear on the surface of the films when annealing in $\mathrm{H}_{2} \mathrm{~S}$-atmosphere. We suggest that this is related to the type of reactive sulfur that is present during each annealing; for $\mathrm{H}_{2} \mathrm{~S}$, the crystallization occurs at the surface of the film where the $\mathrm{H}_{2} \mathrm{~S}$ molecules are present, while for $\mathrm{N}_{2}$, a liquid flux in the form of a K-S phase is believed to aid the merging of the nanoparticles within the film.

\section{ACKNOWLEDGEMENT}

This work was funded by a grant from Innovation Fund Denmark.

\section{REFERENCES}

[1] M. A. Green, K. Emery, Y. Hishikawa, W. Warta, E. D. Dunlop, D. H. Levi, and A. W. Y. Ho-Baillie, "Solar cell efficiency tables (version 49)”, Prog. Photovolt: Res. Appl., vol. 25, pp. 3-13, 2017.

[2] K. Ito, Copper Zinc Tin Sulfide-Based Thin-Film Solar Cells, Nagano, Japan: Wiley, 1st ed., 2015.

[3] S. Engberg, K. Agersted, A. Crovetto, O. Hansen, Y. M. Lam, and J. Schou, "Investigation of $\mathrm{Cu}_{2} \mathrm{ZnSnS}_{4}$ nanoparticles for thinfilm solar cell applications”, Thin Solid Films, vol. 628, pp. 163169, 2017.

[4] X. Liu, F. Zhou, N. Song, J. Huang, C. Yan, F. Liu, K. Sun, J. A. Stride, X. Hao, and M. Green, "Exploring the application of metastable wurtzite nanocrystals in pure-sulfide $\mathrm{Cu}_{2} \mathrm{ZnSnS}_{4}$ solar cells by forming nearly micron-sized large grains”, J. Mater. Chem. A, vol. 3, pp. 23185-23193, 2015.

[5] N. Mirbagheri, S. Engberg, A. Crovetto, S. B. Simonsen, O. Hansen, Y. M. Lam, and J. Schou, "Synthesis of ligand-free CZTS nanoparticles via a facile hot injection route", Nanotechnology, vol. 27, pp. 185603, 2016.

[6] S. Engberg, S. Canulescu, and J. Schou, "Liquid phase assisted grain growth in $\mathrm{Cu}_{2} \mathrm{ZnSnS}_{4}$ nanoparticle thin films by alkali element incorporation”, RCS Adv., vol. 8, pp. 7152-7158, 2018.

[7] D. Braunger, D. Hariskos, G. Bilger, U. Rau, and H. W. Schock, "Influence of sodium on the growth of polycrystalline $\mathrm{Cu}(\mathrm{In}, \mathrm{Ga}) \mathrm{Se}_{2}$ thin films”, Thin Solid Films, vol. 362, pp. 161166, 2000. 